\title{
The effects of zinc amino acid complex on biomarkers of gut integrity, inflammation, and metabolism in heat-stressed ruminants
}

\author{
J. Opgenorth, ${ }^{1}$ M. Abuajamieh, ${ }^{1}$ E. A. Horst, ${ }^{1}$ S. K. Kvidera, ${ }^{1}$ J. S. Johnson, ${ }^{1}$ E. J. Mayorga, ${ }^{1}$ M. V. Sanz- \\ Fernandez, ${ }^{1}$ M. A. Al-Qaisi, ${ }^{1}$ J. M. DeFrain, ${ }^{2}$ D. H. Kleinschmit, ${ }^{2}$ P. J. Gorden, ${ }^{3}$ and L. H. Baumgard ${ }^{1 *}$ \\ ${ }^{1}$ Department of Animal Science, lowa State University, Ames 50011 \\ ${ }^{2}$ Zinpro Corporation, Eden Prairie, MN 55344 \\ ${ }^{3}$ Veterinary Diagnostic and Production Animal Medicine, lowa State University, Ames 50011
}

\section{ABSTRACT}

Study objectives were to evaluate the effects of replacing $40 \mathrm{mg} / \mathrm{kg}$ of dietary Zn from Zn sulfate (ZS) with Zn amino acid complex (ZA; Zinpro Corporation, Eden Prairie, MN) on inflammation and intestinal integrity in heat-stressed and pair-fed $(\mathrm{PF})$ ruminants. Forty Holstein steers $(173.6 \pm 4.9 \mathrm{~kg})$ were randomly assigned to 1 of 5 dietary-environmental treatments: (1) thermoneutral (TN) ad libitum with $75 \mathrm{mg} / \mathrm{kg}$ of dry matter (DM) ZS (ZSCON); (2) TN pair-fed with $75 \mathrm{mg} / \mathrm{kg}$ DM ZS (ZSPF); (3) TN pair-fed with $40 \mathrm{mg} /$ $\mathrm{kg}$ DM ZA and $35 \mathrm{mg} / \mathrm{kg}$ DM ZS (ZAPF); (4) heat stress (HS) ad libitum with $75 \mathrm{mg} / \mathrm{kg}$ DM ZS (ZSHS); and (5) HS ad libitum $40 \mathrm{mg} / \mathrm{kg}$ DM ZA and $35 \mathrm{mg} /$ $\mathrm{kg}$ DM ZS (ZAHS). Before study initiation, calves were fed their respective diets for $21 \mathrm{~d}$. Following the pre-feeding phase, steers were transferred into environmental chambers and were subjected to 2 successive experimental periods. During period 1 ( 5 d), all steers were fed their respective diets ad libitum and housed in $\mathrm{TN}$ conditions $\left(20.2 \pm 1.4^{\circ} \mathrm{C}, 30.4 \pm 4.3 \%\right.$ relative humidity). During period 2 (6 d), ZSHS and ZAHS steers were exposed to cyclical HS conditions (27.1 \pm $1.5^{\circ} \mathrm{C}$ to $35.0 \pm 2.9^{\circ} \mathrm{C}, 19.3 \pm 3.5 \%$ relative humidity), whereas the ZSCON, ZSPF, and ZAPF steers remained in TN conditions and were fed ad libitum or pair-fed relative to their ZSHS and ZAHS counterparts. Overall, steers exposed to HS had markedly increased rectal temperature $\left(0.83^{\circ} \mathrm{C}\right)$, respiration rate $(26$ breaths per min), and skin temperature $\left(8.00^{\circ} \mathrm{C}\right)$ relative to $\mathrm{TN}$ treatments. Rectal temperature from ZAHS steers was decreased $\left(0.24^{\circ} \mathrm{C}\right)$ on d 4 to 6 of HS relative to ZSHS steers. Regardless of diet, HS decreased DMI (18\%) relative to ZSCON steers. Circulating glucose from HS and PF steers decreased (16\%) relative to ZSCON steers. Heat stress and nutrient restriction increased

Received May 15, 2020.

Accepted September 22, 2020.

*Corresponding author: baumgard@iastate.edu circulating nonesterified fatty acids 2- and 3-fold, respectively, compared with ZSCON steers. Serum amyloid A increased $\sim 2$-fold in $\mathrm{PF}$ relative to $\mathrm{ZSCON}$ and HS steers. We detected no treatment effect on blood $\mathrm{pH}$; however, ZAHS steers had increased $\mathrm{HCO}_{3}$ relative to ZSHS. Relative to ZSHS, ZAHS steers had increased jejunum villi height (25\%), a tendency for increased ileum villi height $(9 \%)$, and decreased duodenal villi width $(16 \%)$. In summary, ZA supplementation has some beneficial effects on thermal indices, intestinal architecture characteristics, and biomarkers of leaky gut in heat-stressed steers, indicative of an ameliorated heat load, and thus may be a nutritional strategy to minimize negative consequences of HS.

Key words: leaky gut, inflammation

\section{INTRODUCTION}

Heat stress (HS) jeopardizes human and animal health, and this is mediated in part by reduced intestinal barrier integrity or "leaky gut" (Baumgard and Rhoads, 2013). During HS, blood is directed to the periphery to maximize heat dissipation. A negative outcome of this survival strategy is that blood and nutrient delivery to the gastrointestinal tract is decreased, leading to hypoxia, increased reactive oxygen species production, extracellular membrane damage, and disruption of enterocyte tight junction complexes; this is thoroughly described in rodent and other animal models (Kregel et al., 1988; Hall et al., 1999). Consequently, there is a loss in intestinal barrier integrity and increased susceptibility to antigen permeability and subsequent immune activation and inflammation, as demonstrated in pig and ruminant models (Pearce et al., 2013b; Gabler et al., 2018; Koch et al., 2019; Al-Qaisi et al., 2020). Interestingly, nutrient restriction (a consequence of heat stress) itself negatively affects barrier function in a variety of animal models (Welsh et al., 1998; Ferraris and Carey, 2000; Pearce et al., 2013c), including ruminants (Zhang et al., 2013; Kvidera et al., 2017c). The postabsorptive presence of bacterial components (e.g., LPS) triggers 
an inflammatory cascade mediated by the release of cytokines from macrophages, liver, and other peripheral tissues (Garcia-Lazaro et al., 2005; Lee et al., 2008).

Despite implementing heat abatement strategies, animal productivity remains suboptimal during the warm summer months. Thus, complementary management and dietary approaches are necessary to allow animals the opportunity to meet their genetic potential during HS. In particular, identifying dietary molecules that protect gut barrier health could profoundly enhance animal plasticity. Supplemental Zn improves intestinal barrier function in a variety of animal models (Rodriguez et al., 1996; Sturniolo et al., 2002; Zhong et al., 2015). Additionally, we demonstrated that supplementing $\mathrm{Zn}$ in the form of an amino acid complex (ZA) ameliorates the hyperpermeability effects of HS and feed restriction on inflammation and intestinal health in pigs (Sanz Fernandez et al., 2014; Pearce et al., 2015; Mayorga et al., 2018). Furthermore, ZA modulates the inflammatory response during an acute LPS challenge in dairy cows (Horst et al., 2019). Thus, we hypothesized that supplemental ZA would help maintain intestinal epithelia architecture and reduce inflammatory markers in an HS ruminant model.

\section{MATERIALS AND METHODS}

\section{Experimental Design and Diets}

All procedures were approved by the Iowa State University Animal Care and Use Committee (Ames, IA). Forty Holstein steers were enrolled in an experiment conducted in 3 replicates [BW 153, 172, and $178 \pm$ $4 \mathrm{~kg}( \pm \mathrm{SD})$, for replicates 1,2 , and 3, respectively] at the Iowa State Zumwalt Research Station (Ames, IA). The number of animals selected per treatment was based upon the expected variation observed in previous experiments (Sanz Fernandez et al., 2014; Pearce et al., 2015; Mayorga et al., 2018). The experiment was conducted from November 2014 to February 2015. Steers were randomly assigned to 1 of 2 dietary treatments: (1) a diet containing $75 \mathrm{mg} / \mathrm{kg}$ of $\mathrm{Zn}$ from $\mathrm{ZnSO}_{4}(\mathbf{Z S}$; $\mathrm{n}=24)$ or (2) a diet containing $35 \mathrm{mg} / \mathrm{kg} \mathrm{Zn}$ from $\mathrm{ZnSO}_{4}$ and $40 \mathrm{mg} / \mathrm{kg} \mathrm{Zn}$ from ZA (ZA; $\mathrm{n}=16$; Availa Zn, Zinpro Corporation, Eden Prairie, MN). All diets contained the same quantity of supplemental zinc, and only the proportion of zinc source differed between treatments (ZS or ZA). We considered both beef and dairy requirements when determining Zn level. The NRC (2000) recommended level for feedlot beef cattle is 30 $\mathrm{mg} \mathrm{Zn} / \mathrm{kg}$ DM. However, a survey of feedlot consulting nutritionists (Vasconcelos and Galyean, 2007) indicated that feedlot diets are formulated to contain, on average, $93 \mathrm{mg} / \mathrm{kg}$ Zn (range of 40 to $213 \mathrm{mg} / \mathrm{kg}$ ). Dairy NRC
(2001) recommends 18 to $73 \mathrm{mg} / \mathrm{kg}$ of DM, depending upon the cow's life cycle stage and DMI. Therefore, we selected the upper end of the dairy requirement but close to the typical level of $\mathrm{Zn}$ fed to feedlot cattle. The proportion supplied by ZA was based on previous work by Nayeri et al. (2014) showing beneficial effects on production parameters in dairy cattle. The zinc in ZA was bound to 1 of 16 potential amino acids in a ratio of 1 atom of metal bound to a single, unspecified amino acid. Before the start of the study, steers were fed their respective diets for $21 \mathrm{~d}$. Following this initial feeding phase, steers were moved into individual pens $(1.00 \times$ $2.50 \mathrm{~m}$ ) within environmental chambers. Steers were allowed $3 \mathrm{~d}$ to acclimate to their pens before data collection began. Diets were formulated to meet or exceed the predicted requirements (NRC, 2001) for energy, protein, minerals, and vitamins (Table 1).

Diets were mixed on a daily basis using a concrete mixer (model-600 series, Kushlan Products LLC, Sugar Land, TX) by adding 3 different components: (1) cracked corn, (2) corn silage, and (3) 1 of 2 types

Table 1. Ingredients and composition of nutrients in diets supplemented with zinc sulfate (ZS) or zinc amino acid complex (ZA)

\begin{tabular}{|c|c|c|}
\hline Item & $\mathrm{ZS}$ & $\mathrm{ZA}$ \\
\hline \multicolumn{3}{|l|}{ Ingredient, \% } \\
\hline Corn grain, cracked & 42.4 & 43.4 \\
\hline Corn silage & 13.9 & 14.2 \\
\hline Treatment pellet $^{1}$ & 43.7 & 42.4 \\
\hline \multicolumn{3}{|l|}{ Nutrient analysis } \\
\hline DM, \% & 72.6 & 70.8 \\
\hline $\mathrm{CP}, \%$ & 15.73 & 16.29 \\
\hline $\mathrm{ADF}, \%$ & 14.54 & 14.95 \\
\hline NDF, $\%$ & 23.15 & 23.97 \\
\hline Ash-free NDF, \% & 22.19 & 23.12 \\
\hline Lignin, $\%$ of sulfuric acid & 1.59 & 1.49 \\
\hline Lignin, \% of NDF & 6.64 & 6.14 \\
\hline Acid detergent insoluble $\mathrm{CP}, \%$ of $\mathrm{CP}$ & 6.90 & 6.18 \\
\hline Acid detergent insoluble CP, \% of DM & 0.94 & 1.00 \\
\hline Neutral detergent insoluble $\mathrm{CP}, \%$ of $\mathrm{CP}$ & 10.28 & 10.27 \\
\hline Neutral detergent insoluble CP, \% of DM & 1.79 & 1.87 \\
\hline Soluble protein, \% of CP & 30.76 & 30.95 \\
\hline Ether extract, \% & 5.01 & 5.07 \\
\hline Ash, \% & 5.85 & 5.91 \\
\hline Calcium, \% & 0.88 & 0.85 \\
\hline Phosphorous, \% & 0.39 & 0.40 \\
\hline Magnesium, \% & 0.20 & 0.22 \\
\hline Potassium, \% & 0.86 & 0.93 \\
\hline Sulfur, \% & 0.26 & 0.32 \\
\hline Manganese, $\mathrm{mg} / \mathrm{kg}$ & 99.19 & 91.81 \\
\hline Zinc, $\mathrm{mg} / \mathrm{kg}$ & 108.46 & 113.43 \\
\hline Copper, mg/kg & 15.55 & 14.65 \\
\hline Iron, $\mathrm{mg} / \mathrm{kg}$ & 228.70 & 507.28 \\
\hline Sodium, \% & 0.13 & 0.12 \\
\hline Chlorine, \% & 0.26 & 0.25 \\
\hline Molybdenum, mg/kg & 0.54 & 0.55 \\
\hline Selenium, mg/kg & 0.54 & 0.55 \\
\hline Cobalt, mg/kg & 1.38 & 1.58 \\
\hline
\end{tabular}

${ }^{1}$ Treatment pellet DM composition, ZS: $27 \%$ CP, $8 \%$ fat, $7 \%$ starch, $20 \% \mathrm{ADF}, 10 \%$ ash with $185 \mathrm{mg} / \mathrm{kg} \mathrm{Zn;} \mathrm{ZA:} 26 \% \mathrm{CP}, 8 \%$ fat, $8 \%$ starch, $21 \%$ ADF, $10 \%$ ash with $267 \mathrm{mg} / \mathrm{kg} \mathrm{Zn}$. 
of pellets (Kent Nutrition Group Inc., Muscatine, IA) containing adequate quantities of $\mathrm{Zn}$ either from $\mathrm{ZS}$ or from both ZS and ZA (Table 1).

Feed samples of mixed diets and individual components were collected weekly. Samples from all 3 replicates were composited into a single representative feed sample per diet (ZS or ZA; Table 1). Corn silage was dried and ground using a 2-mm screen before being composited. Samples were submitted to Dairyland Laboratories Inc. (Arcadia, WI) and analyzed via wet chemistry methods. Additional trace minerals Co and Se were analyzed by Midwest Laboratories Inc. (Omaha, NE) and SDK Laboratories (Hutchinson, KS), respectively (Table 1), as previously described (Nayeri et al., 2014). Drinking water was sampled at the beginning and end of the experiment after letting the water run freely for 2 min. Samples were immediately submitted to Dairyland Laboratories Inc. for analyses using their Livestock Water Package (Table 2), as we have previously described (Nayeri et al., 2014).

\section{Data Collection Phase}

The data collection phase of the trial consisted of 2 experimental periods. Period 1 (P1) lasted $5 \mathrm{~d}$ and served as the baseline (data generated for covariate analysis) during which all steers were in thermoneutral (TN) conditions and fed their respective diets ad libitum. During period 2 (P2; 6 d), ZS and ZA steers were exposed to either TN or HS conditions. Thermoneutral conditions were $20.2 \pm 1.4^{\circ} \mathrm{C}, 30.4 \pm$ $4.3 \%$ relative humidity, and temperature-humidity index of 64 . Heat stress conditions were cyclical and ranged from 27 to $35^{\circ} \mathrm{C}\left(35.0 \pm 2.9^{\circ} \mathrm{C}, 19.3 \%\right.$ relative humidity, temperature-humidity index $=78$ from 1000 to $1600 \mathrm{~h}$, and $27.1 \pm 1.5^{\circ} \mathrm{C}, 24.2 \%$ relative humidity, temperature-humidity index $=71$ from 1600 to $1000 \mathrm{~h}$ ). Ambient temperature was controlled, but humidity was not governed, and both parameters were recorded every 5 min by a data logger (Lascar EL-USB-2-LCD, Erie, PA). Dietary and environmental combinations resulted in 5 treatments in total: TN ad libitum (ZSCON; $\mathrm{n}$ $=8)$, TN pair-fed (ZSPF, $\mathrm{n}=8$ ), or HS ad libitum (ZSHS; $\mathrm{n}=8$ ) conditions, and steers receiving the ZA diet were assigned to $\mathrm{TN}$ pair-fed (ZAPF, n $=8$ ) or HS ad libitum (ZAHS; $\mathrm{n}=8$ ) conditions.

Ad libitum-fed treatments (ZSCON, ZSHS, ZAHS) were fed twice daily at 0800 and $1900 \mathrm{~h}$, and orts were recorded daily before the a.m. feeding. The ZSPF and ZAPF steers were pair-fed to their ZSHS and ZAHS counterparts, respectively, to eliminate the confounding effect of dissimilar nutrient intake, as we have previously described (O'Brien et al., 2010; Mayorga et al., 2018). For this purpose, the P1 feed intake was averaged
Table 2. Water analysis at the beginning and at the end of the project

\begin{tabular}{lcc}
\hline Item & Pre-project & Post-project \\
\hline Nitrate-N, mg/kg & 1.28 & 1.97 \\
$\mathrm{pH}$ & 9.13 & 8.72 \\
Calcium, $\mathrm{mg} / \mathrm{kg}$ & 97.38 & 53.00 \\
Magnesium, mg/kg & 6.25 & 7.78 \\
Phosphorous, mg/kg & 0.09 & 0.10 \\
Potassium, mg/kg & 3.60 & 2.77 \\
Copper, mg/kg & 0.02 & 0.02 \\
Iron, mg/kg & 0.09 & 0.05 \\
Zinc, mg/kg & 0.13 & 0.03 \\
Sodium, mg/kg & 41.07 & 21.78 \\
Manganese, mg/kg & 0.003 & 0.005 \\
Chloride, mg/kg & 60 & 51 \\
Sulfate, mg/kg & 102 & 86.6 \\
Total dissolved solids, mg/kg & 355 & 310 \\
Hardness, mg/L & 274 & 172 \\
\hline
\end{tabular}

for each steer and used as a baseline. For each ZSHS and ZAHS steer, the decrease in feed intake during P2 was calculated as the percentage of feed intake reduction relative to $\mathrm{P} 1$ for each day of HS exposure. This percentage of feed intake reduction was averaged for all ZSHS or ZAHS steers per day of exposure and applied individually to the baseline of each ZSPF and ZAPF steer, respectively. Daily feed allowance was divided equally and fed at 0800 and $1900 \mathrm{~h}$.

\section{Body Temperature Indices}

During both P1 and P2, rectal temperature (Tr), skin temperature, and respiration rate were measured thrice daily at 0700, 1200, and 1900 h. Rectal temperatures were measured using a standard digital thermometer (M700 Digital Thermometer, GLA Agricultural Electronics, San Luis Obispo, CA). Skin temperatures were measured on the rump area using an infrared thermometer (IR Thermometer 42505, EXTECH Instruments, Nashua, NH). Respiration rate was determined by observing flank movements during a 15-s interval and converting into breaths per minute by multiplying by 4 .

\section{Blood Parameters and Analyses}

A jugular catheter was implanted in all steers on $\mathrm{d} 2$ of P1. Blood samples were collected daily throughout $\mathrm{P} 2$ at $0600 \mathrm{~h}$ before feeding into glass tubes containing 250 United States Pharmacopeia units of sterile heparin. Plasma was harvested following centrifugation at $1,500 \times g$ for $15 \mathrm{~min}$ at $4^{\circ} \mathrm{C}$, and subsequently frozen at $-20^{\circ} \mathrm{C}$ until further analysis. An additional blood sample was collected before euthanasia the day following the end of $\mathrm{P} 2 \mathrm{~d} 6$.

Plasma insulin, nonesterified fatty acids (NEFA), glucose, LPS binding protein (LBP), L-lactate, serum 
amyloid A (SAA), haptoglobin (Hp), and BUN concentrations from d 3,4 , and 5 of $\mathrm{P} 1, \mathrm{~d} 1,3$, and 5 of P2 were determined using commercially available kits according to manufacturers' instructions (insulin: Mercodia AB, Uppsala, Sweden; NEFA: Wako Chemicals USA, Richmond, VA; glucose: Wako Chemicals USA; LBP: Hycult Biotech, Uden, Netherlands; L-lactate: Biomedical Research Service Center, Buffalo, NY; SAA: Tridelta Development Ltd., Kildare, Ireland; Hp: Immunology Consultants Laboratory Inc., Portland, OR; BUN: Teco Diagnostics, Anaheim, CA). The intraand interassay coefficients of variation for the insulin, NEFA, glucose, L-lactate, SAA, Hp, LBP, and BUN assays were 11.1 and $4.8 \%, 4.2$ and $11.8 \%, 8.0$ and $5.7 \%$, 3.7 and $10.0 \%, 6.8$ and $23.5 \%, 3.4$ and $17.0 \%, 4.9$ and $14.7 \%$, and 8.1 and $12.9 \%$, respectively.

To measure the effects of HS and Zn source on blood gas system strain, fresh blood was collected on d 5 of $\mathrm{P} 1$, and $\mathrm{d} 3$ and 5 of $\mathrm{P} 2$, into lithium heparin tubes and assayed immediately using an i-STAT hand-held blood analyzer (CG8+ cartridge; MN:300-G; Abbott Point of Care Inc., Abbot Park, IL), which measured blood $\mathrm{pH}$, partial pressure of carbon dioxide $\left(\mathbf{p C O}_{2}\right)$, oxygen pressure, saturated oxygen percentage, base excess $(\mathbf{B E x})$, hematocrit, total carbon dioxide $\left(\mathbf{T} \mathbf{C O}_{2}\right)$, sodium, potassium, ionized calcium, hemoglobin, and bicarbonate $\left(\mathrm{HCO}_{3}\right)$ concentrations.

\section{Postmortem Tissue Collection and Analyses}

The day following P2 d 6 , steers were transported to the Iowa State Livestock Infectious Disease Isolation Facility (Ames) and euthanized with a CASH Special captive bolt gun (Accles and Shelvoke Ltd., Sutton Coldfield, West Midlands, UK) using a large animal charge. Intestinal tissues were harvested within $5 \mathrm{~min}$ following euthanasia. Duodenum was collected $15 \mathrm{~cm}$ distal to the pyloric sphincter. Jejunum was collected 80 $\mathrm{cm}$ distal to the pyloric sphincter. Ileum was collected $15 \mathrm{~cm}$ proximal to the ileocecal junction. Descending colon was collected $30 \mathrm{~cm}$ proximal to the pelvic inlet. Intestinal samples $(\sim 20-30 \mathrm{~cm})$ were flushed with cold PBS to remove luminal contents, fixed in $10 \%$ neutral buffered formalin for $24 \mathrm{~h}$, and transferred to $70 \%$ ethanol for later histological analysis. For histological analysis, formalin-fixed duodenum, ileum, jejunum, and colon samples were submitted to the Iowa State University Veterinary Diagnostic Laboratory (Ames) for sectioning and periodic acid-Schiff (PAS) staining. One slide per steer per tissue was generated. Using a microscope (DMI3000 B Inverted Microscope, Leica, Bannockburn, IL) with an attached camera (12-bit QICAM Fast 1394, QImaging, Surrey, BC, Canada), 5 images per section of intestine were obtained at $50 \times$ magnification. All image processing and quantification was performed using ImageJ version 1.48 (National Institutes of Health, Fort Collins, CO). Villus height was measured from the tip to the level of the villus-crypt interface using the segmented line tool along the villus midline. Villus width was measured using a single line at mid-villus height. Crypt depth was measured with a single line from the villus-crypt interface to the laminae propria and muscularis mucosa junction. The area occupied by goblet cells was determined by thresholding as the percentage of PAS stained area relative to total tissue area. Results of the 5 pictures per intestinal section were condensed into a single average per steer. Two villi per image were quantified for villus height, width, and crypt depth, for a total of 10 measurements per intestinal segment per steer for each metric (villus height, width, and depth). For goblet cell area, the full image was quantified, and therefore only 1 measurement per image was evaluated, for a total of 5 measurements per intestinal segment per steer.

\section{Statistical Analysis}

The effect of treatment (ZSCON, ZSPF, ZSHS, ZAPF, and ZAHS) on variables with single measures was analyzed using PROC MIXED of SAS (version 9.4; SAS Institute Inc., Cary, NC). For variables with multiple measurements over time, a repeated measures analysis with an autoregressive covariance structure and day as the repeated effect was used to determine the effects of treatment, day, and treatment by day interaction. Replicate 1 and 2 contained an equal number of animals per treatment in the ZSCON, ZSHS, and ZAHS treatments. Because the DMI decrease in response to HS is highly variable, it likely would have resulted in pair-fed $(\mathbf{P F})$ animals having a dissimilar level of feed intake reduction per replicate. Thus, PF treatments were carried out in replicate 3 , and replicate was not included in the model. Each specific variable's P1 value (when available) served as a covariate. For both single and repeated measure variables, the following preplanned contrasts were evaluated: ZS versus ZA, ZSPF versus ZAPF, ZSHS versus ZAHS, and HS versus $\mathrm{PF}$ using the CONTRAST statement of SAS. Results are reported as least squares means and considered significant when $P \leq 0.05$ and a tendency when $0.05<$ $P \leq 0.10$.

\section{RESULTS}

Steers exposed to HS had markedly increased $\mathrm{Tr}$ $\left(0.83^{\circ} \mathrm{C} ; P<0.01\right)$, skin temperature $\left(8.00^{\circ} \mathrm{C} ; P<\right.$ 0.01 ), and respiration rate (26 breaths per minute; $P<0.01)$ throughout P2 compared with TN steers 
(Table 3). Compared with ZSHS, Tr from ZAHS steers decreased between $\mathrm{d} 4$ and d 6 of $\mathrm{P} 2\left(0.24^{\circ} \mathrm{C} ; P<\right.$ 0.01; Figure 1), but dietary treatments had no effect in TN conditions. During P2, HS caused a progressive decrease in DMI for both ZSHS and ZAHS $(18 \% ; P$ $\leq$ 0.03; Table 3) compared with ZSCON steers. By design, the pattern and extent of feed intake reduction was similar $(P=0.92$; Table 3$)$ between PF steers and their HS counterparts.

Effects on metabolic and inflammatory parameters analyzed from blood are reported in Table 4. Relative to ZSCON, blood glucose decreased similarly for all treatments $(16 \% ; P=0.01)$, and the increase in blood NEFA was less severe in HS compared with PF steers (1.9- vs. 3.0-fold; $P<0.01$ ). Circulating BUN was increased in ZSHS but not ZAHS, compared with ZSCON and PF (46\%; $P=0.02)$. No overall treatment differences were detected for plasma insulin $(P=$ 0.19 ), although concentrations tended to increase in HS compared with PF steers (1.2 fold; $P=0.08)$. Insulin increased over time regardless of treatment $(P=0.05)$.

Regardless of $\mathrm{Zn}$ source, circulating SAA increased in PF treatments from $\mathrm{d} 3$ to $\mathrm{d} 7$ ( 3.4 -fold; Table $4)$, whereas concentrations remained stable for ad libitum treatments over time. This resulted in an overall decrease in circulating SAA in HS compared with PF steers $(50 \% ; P=0.03)$. Plasma LBP was increased on d 3 relative to $\mathrm{d} 7$ in $\mathrm{PF}$ animals (2.6- and 1.7-fold; $P=0.02$ and 0.04 for ZAPF and ZSPF, respectively; Table 4). Likewise, ZSHS LBP increased over time (d3 vs. d7; 1.9 -fold; $P=0.04$ ); in contrast, ZAHS numerically decreased LBP (2-fold). Plasma Hp and L-lactate increased with time in all treatments $(P \leq 0.03$; Table $4)$. Furthermore, the increase in L-lactate over time was greater in HS compared with PF $(13 \% ; P=0.05$; Table 4).

We detected a treatment by day interaction for blood $\mathrm{pH}, \mathrm{pCO}_{2}, \mathrm{Na}$, and $\mathrm{K}(P \leq 0.04$; Supplemental Table S1, https://doi.org/10.3168/jds.2020-18909). An overall treatment effect $(P<0.01)$ was detected on blood $\mathrm{HCO}_{3}$, as it was increased in ZSPF steers (6\%), did not differ in ZAPF, and was decreased in the HS animals (9\%) compared with ZSCON; however, $\mathrm{HCO}_{3}$ decreased with time in all steers $(P=0.01)$. Furthermore, the observed decrease in $\mathrm{HCO}_{3}$ was less severe in ZAHS compared with ZSHS (6\% vs. $11 \% ; P \leq 0.03$ ). Steers exposed to HS (regardless of $\mathrm{Zn}$ source) had lower $\mathrm{TCO}_{2}$ and BEx (9\% and 57\%, respectively; $P<$ $0.01)$ compared with all TN treatments. Additionally, ZAHS steers tended to have increased BEx $(\sim 2$-fold; $P$ $=0.08$ ) compared with ZSHS steers.

Gut morphology was altered by nutritional and environmental treatments (Table 5; Figure 2). Overall, dietary ZA increased jejunum villus height compared with ZS steers, and this was most pronounced during HS $(P<0.01)$. Similarly, ZA supplementation (regardless of the thermal conditions) tended to increase ileum villi height, compared with ZS steers (15 and 9\%; $P=0.02$ and 0.09; Table 5). Regardless of thermal conditions, ZA decreased and tended to decrease duodenum and jejunum villi width, respectively, relative to ZS steers (9 and $12 \% ; P=0.04$ and 0.08$)$. Crypt depth was similar between treatments in all intestinal tissues. Ratio of jejunum villi height to crypt depth tended to increase in ZAHS compared with other treatments $(26 \% ; P=$ 0.06). Moreover, ZA increased the ratio of jejunum villi height to crypt depth compared with ZS (18\%; $P$ $=0.03)$. The ZAHS treatment increased ratio of villi height to crypt depth in the jejunum and tended to increase it in the ileum compared with ZSHS $(P=0.01$ and 0.07 , respectively). Overall, goblet cell area was similar throughout the intestine for all steers, excluding all PF steers, which exhibited decreased goblet cell area along the gastrointestinal tract $(\sim 2$ - to 2.5 -fold; $P \leq$ 0.02 ; Table 5) compared with both the ZSCON and the HS steers.

\section{DISCUSSION}

Results presented herein demonstrate our model successfully implemented a meaningful heat load, and the HS effects were partially attenuated by ZA supplementation. Heat stress causes intestinal hyperpermeability by instigating heat dissipation mechanisms that divert blood flow from the viscera to the periphery, resulting in diminished enterocyte oxygen and nutrient supply, as reported in rodent models (Kregel et al., 1988; Hall et al., 1999). Hyperthermia additionally induces hypophagia (Kadzere et al., 2002), which by itself also causes intestinal barrier dysfunction in pigs and dairy cows (Pearce et al., 2014; Kvidera et al., 2017c). In the current experiment, reasons why we did not detect HS-induced changes in the indirect metrics of intestinal permeability (inflammatory markers and intestinal architecture) are unclear, but potential reasons include the following: model differences (growing vs. lactating ruminants), species (porcine vs. bovine), timing of sacrifice (gastrointestinal tract had time to adapt and recover from the insult), and others. Regardless, this highlights the need for identifying an accessible and more accurate biomarker of gut barrier function.

Zinc supplementation ameliorates intestinal dysfunction from HS (Sanz Fernandez et al., 2014; Pearce et al., 2015) and malnutrition (Rodriguez et al., 1996; Pearce et al., 2015). Although the mechanisms by which Zn improves gut health are not fully understood, one possibility could be via upregulating tight junction proteins, as demonstrated in humans (Finnamore et 
Opgenorth et al.: ZINC SUPPLEMENTATION DURING HEAT STRESS

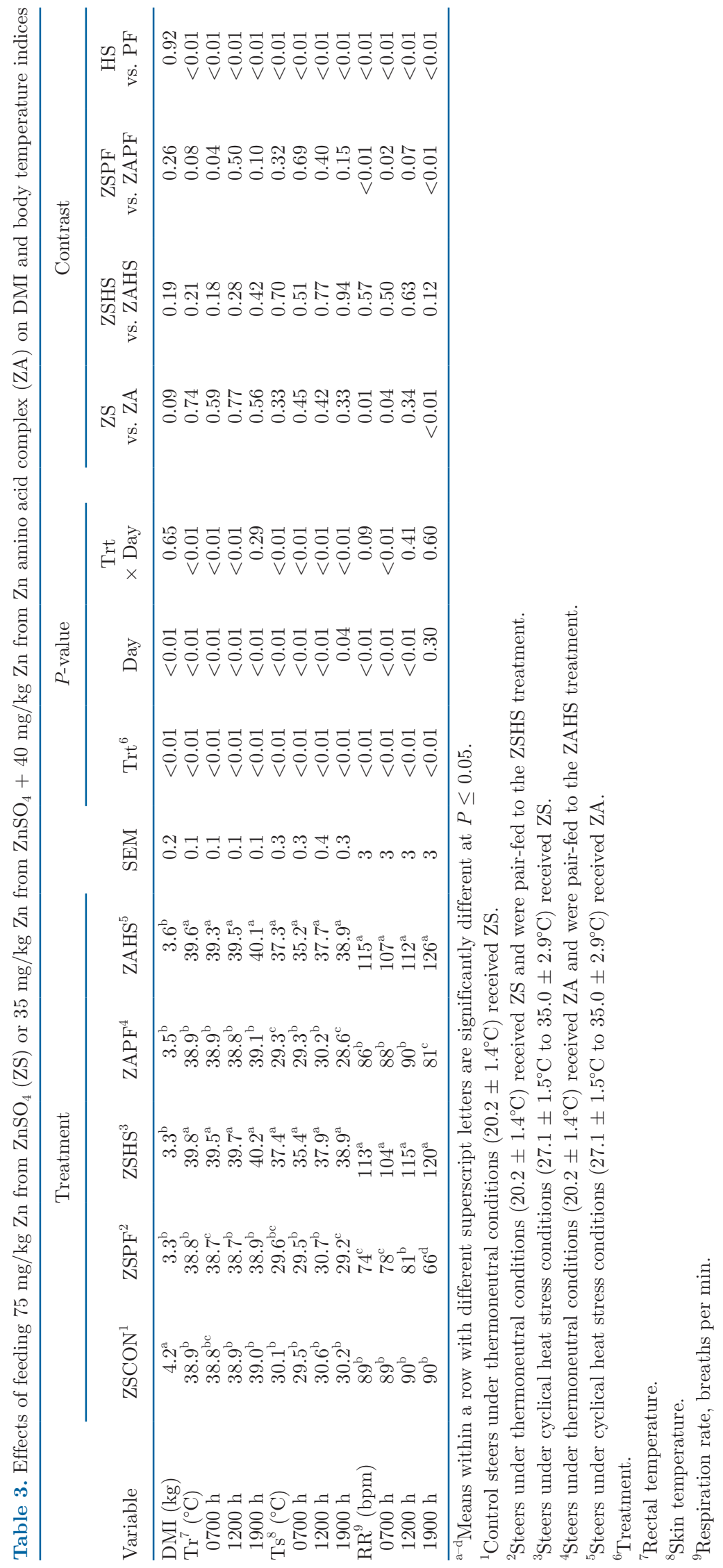


al., 2008; Wang et al., 2013; Sarkar et al., 2019). Zinc is also an integral component of antioxidant enzymes (Waeytens et al., 2009; Eze et al., 2015), and oxidative stress is thought to be one of the initial insults contributing to leaky gut (Pearce et al., 2013b; Liu et al., 2016). Additionally, Noah et al. (2011) highlighted the importance of $\mathrm{Zn}$ for regeneration and localization of gut stem cells. Zinc may also directly alter cytokine production via Zn-finger protein inhibition of the nuclear factor kappa-light-chain enhancer of activated B cells pathway (Foster and Samman, 2012; Jarosz et al., 2017). Benefits on gut health and the inflammatory response are also observed when a more bioavailable $\mathrm{Zn}$ form is fed, particularly during challenges such as HS, endotoxin insult, or Crohn's disease (Sturniolo et al., 2001; Pearce et al., 2015; Mayorga et al., 2018; Horst et al., 2019). Because of the aforementioned results, we hypothesized that supplemental dietary ZA would improve gut health compared with ZS in ruminants exposed to HS conditions.

In the current study, cyclical HS increased all body temperature indices and reduced DMI (18\%), which was indicative of heat strain. Interestingly, Tr from ZAHS steers were reduced $\left(0.24^{\circ} \mathrm{C}\right)$ from d 4 to d 6 compared with ZSHS. This response in ZA-supplemented steers agrees with our previous report in heat-stressed pigs (Pearce et al., 2015) and in immunoactivated lactating dairy cows (Horst et al., 2019) and presumably (although not confirmed with the variables measured in the current experiment) stems from reducing the febrile portion of increased Tr during HS due to blunted immune activation. We hypothesize this is explained by improved intestinal barrier function and thus reduced infiltration of luminal contents to trigger leukocyte activation and inflammatory cytokine production (Mayorga et al., 2018). The reduced $\mathrm{Tr}$ is even more noteworthy because DMI tended to increase in ZA-supplemented steers compared with ZS. Thus, the heat increment of feeding was ostensibly increased in the ZA-fed animals.

Many studies report that HS alters intestinal morphology in monogastrics (i.e., decreased villi height, increased villi width, and other effects; Yan et al., 2006; Hou et al., 2012; Ashraf et al., 2013; Pearce et al., 2013b; Sanz Fernandez et al., 2014), indicative of decreased intestinal epithelial integrity (Lambert et al., 2002; Santos et al., 2015). As mentioned, HS did not have an overall main effect on most of the gastrointestinal tract metrics, but compared with ZS, ZA improved intestinal morphology in both PF and HS conditions, which may reflect an improved intestinal barrier. Feeding ZA

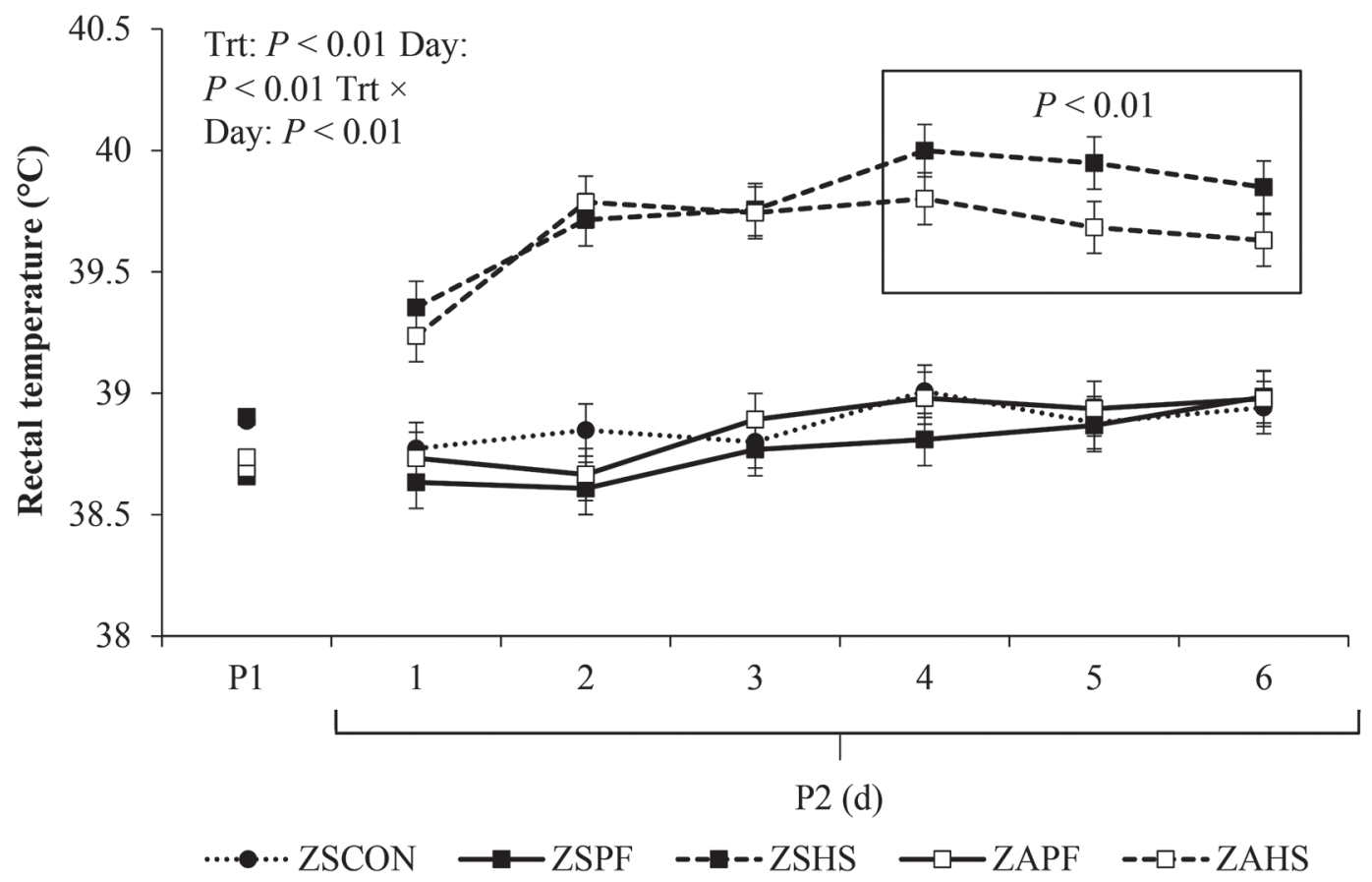

Figure 1. Effects of replacing $40 \mathrm{mg} / \mathrm{kg} \mathrm{Zn} \mathrm{sulfate} \mathrm{(ZS)} \mathrm{with} \mathrm{Zn} \mathrm{amino} \mathrm{acid} \mathrm{complex} \mathrm{(ZA)} \mathrm{on} \mathrm{rectal} \mathrm{temperature} \mathrm{in} \mathrm{growing} \mathrm{steers} \mathrm{exposed}$ to thermoneutral or cyclical heat stress conditions. Treatments: ZSCON $=$ thermoneutral ad libitum control diet, ZSPF $=$ pair-fed $75 \mathrm{mg} / \mathrm{kg}$ ZS diet, ZAPF = pair-fed $40 \mathrm{mg} / \mathrm{kg} \mathrm{ZA}$ and $35 \mathrm{mg} / \mathrm{kg} \mathrm{ZS,} \mathrm{ZSHS} \mathrm{=} \mathrm{heat} \mathrm{stress} \mathrm{ad} \mathrm{libitum} 75 \mathrm{mg} / \mathrm{kg}$ ZS diet, and ZAHS = heat stress ad libitum $40 \mathrm{mg} / \mathrm{kg} \mathrm{ZA}$ and $35 \mathrm{mg} / \mathrm{kg} \mathrm{ZS}$ diet. P1 represents an average of measurements obtained during baseline and was used as a covariate for period 2 (P2) analysis. Effects of treatment (Trt), day, and treatment by day were assessed as a complete randomized design using PROC MIXED of SAS (version 9.4; SAS Institute Inc., Cary, NC). Data are represented as LSM \pm SEM. 


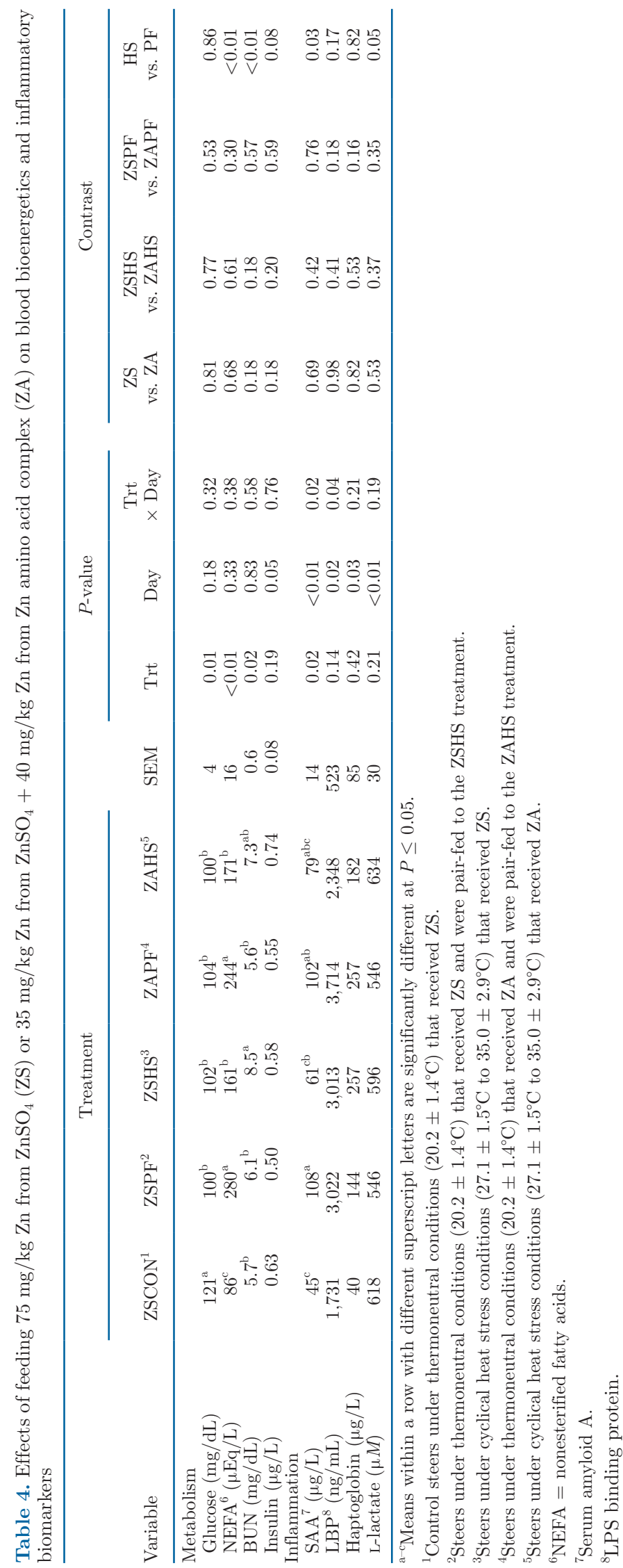

seems to be particularly effective in the jejunum, where villi height:depth ratio increased in both $\mathrm{TN}$ and $\mathrm{HS}$ conditions. The jejunum is the primary site of nutrient absorption, and alterations at this segment may affect feed utilization. Additionally, ZAHS steers tended to have increased ileum villi height:depth ratio. These findings corroborate research demonstrating that ZA acutely and chronically improves multiple in vivo and ex vivo indicators of leaky gut in pigs (Sanz Fernandez et al., 2014; Pearce et al., 2015; Mayorga et al., 2018).

Inflammation occurs in response to leaky gut-induced immune activation, and it stimulates hepatocytes to produce acute-phase proteins (APP; Ceciliani et al., 2012). Acute-phase proteins are involved in pathogen opsonization, removal of toxic substances, and regulation of the immune system response to inflammation (Steel and Whitehead, 1994; Ceciliani et al., 2012). In the current study, APP concentrations for LBP and Hp were not different across treatments, although a decrease was observed over time. Pair-fed steers had increased SAA concentrations compared with HS steers. Although both HS and feed restriction damage the intestinal barrier in rodents, pigs, and dairy cattle (Goodlad et al., 1988; Pearce et al., 2013c; Kvidera et al., 2017c; Koch et al., 2019), HS-induced heat shock proteins blunt production of proinflammatory cytokines (Dokladny et al., 2010) but do not appear to prevent an APP response (Gabler et al., 2018). Thus, it remains unknown what mechanisms explain reduced APP in HS animals compared with the feed-restricted controls.

The liver requires an increased supply of amino acids for APP production, and the activated immune response increases energy demands (Kvidera et al., 2017a). Muscle protein catabolism makes available gluconeogenic precursors to fuel-activated immune cells (Wannemacher et al., 1980) and provides additional amino acids for APP synthesis (Iseri and Klasing, 2013), although, as aforementioned, we curiously did not detect an increase in circulating APP. Consequently, protein metabolism is affected by HS, as muscle catabolism biomarkers such as BUN are increased during HS (Yoshizawa et al., 1997; Yunianto et al., 1997; Pearce et al., 2013a; Al-Qaisi et al., 2020). In agreement, BUN levels were increased in HS steers irrespective of the $\mathrm{Zn}$ form fed and substantially increased compared with the $\mathrm{PF}$ steers, although ZAHS had numerically reduced BUN relative to ZSHS, whereas ZAHS did not statistically differ from ZSCON, ZSPF, or ZAPF BUN values.

Despite HS-induced decreased feed intake during P2, circulating insulin levels remained similar between HS and ZSCON steers and tended to increase in HS relative to $\mathrm{PF}$ steers; this is a fairly conserved species response (Baumgard and Rhoads, 2013). Increased circulating insulin might be associated with altered 
Table 5. Effects of feeding $75 \mathrm{mg} / \mathrm{kg} \mathrm{Zn}$ from ZnSO4 (ZS) or $35 \mathrm{mg} / \mathrm{kg} \mathrm{Zn} \mathrm{from} \mathrm{ZnSO}_{4}+40 \mathrm{mg} / \mathrm{kg}$ Zn from Zn amino acid complex (ZA) on intestinal morphology

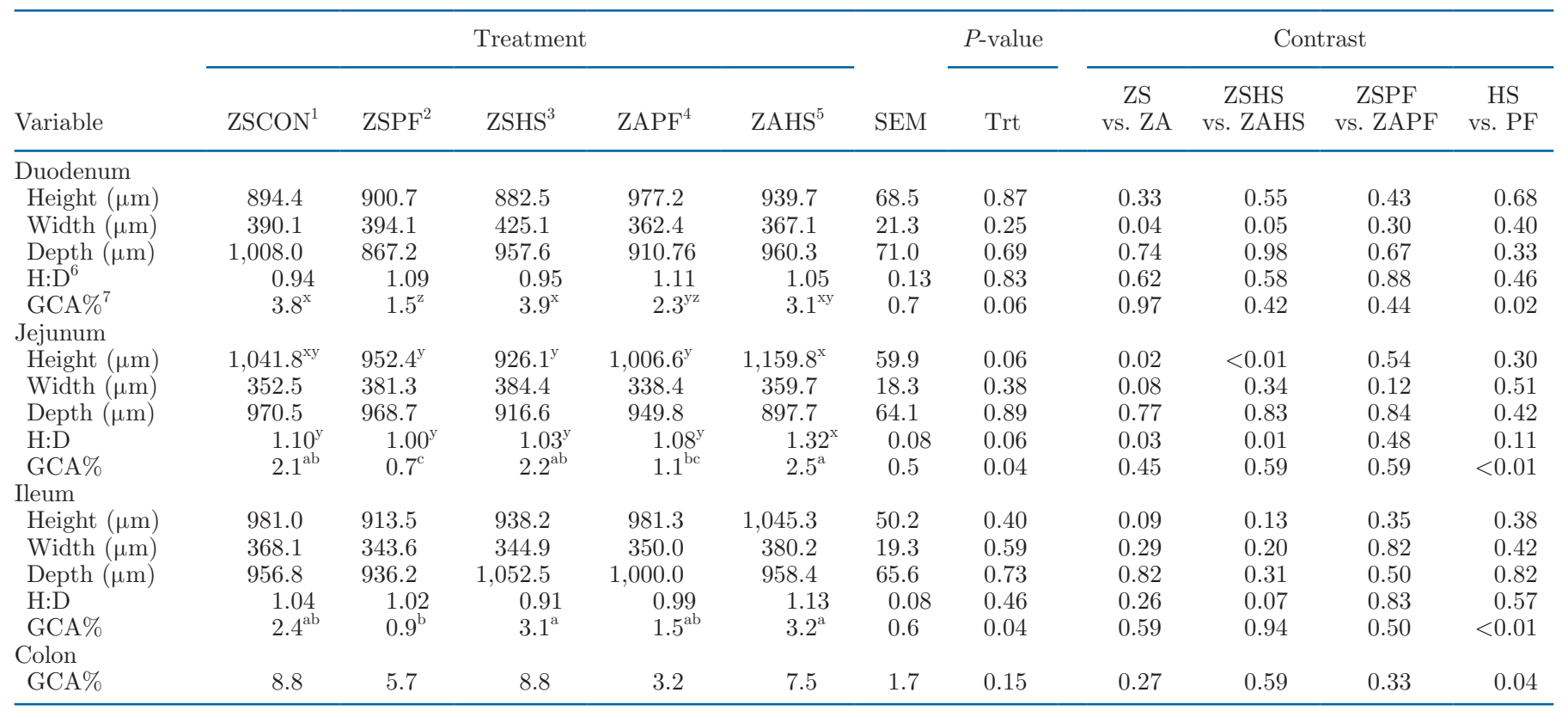

${ }^{\mathrm{a}-\mathrm{c}}$ Means within a row with different superscript letters are significantly different at $P \leq 0.05$

${ }^{\mathrm{x}-\mathrm{z}}$ Means within a row with different superscript letters are significantly different at $0.05<P \leq 0.10$.

${ }^{1}$ Control steers under thermoneutral conditions $\left(20.2 \pm 1.4^{\circ} \mathrm{C}\right)$ that received ZS.

${ }^{2}$ Steers under thermoneutral conditions $\left(20.2 \pm 1.4^{\circ} \mathrm{C}\right)$ that received ZS and were pair-fed to the ZSHS treatment.

${ }^{3}$ Steers under cyclical heat stress conditions $\left(27.1 \pm 1.5^{\circ} \mathrm{C}\right.$ to $\left.35.0 \pm 2.9^{\circ} \mathrm{C}\right)$ that received ZS.

${ }^{4}$ Steers under thermoneutral conditions $\left(20.2 \pm 1.4^{\circ} \mathrm{C}\right)$ that received ZA and were pair-fed to the ZAHS treatment.

${ }^{5}$ Steers under cyclical heat stress conditions $\left(27.1 \pm 1.5^{\circ} \mathrm{C}\right.$ to $\left.35.0 \pm 2.9^{\circ} \mathrm{C}\right)$ that received ZA.

${ }^{6}$ Villus height:crypt depth.

${ }^{7}$ Goblet cell area, expressed as a percentage of epithelial area.

intestinal integrity (a pathology, albeit not confirmed in the current experiment), as endotoxin appears to augment insulin secretion in a variety of ruminant and monogastric models. For example, intramammary endotoxin infusion increased circulating insulin in lactating dairy cows (Waldron et al., 2006). Further, we have extensively demonstrated that i.v.-infused endotoxin in pigs, steers, and dairy cows acutely increases circulating insulin (Kvidera et al., 2017a,b; Horst et al., 2019). Immune cells are insulin sensitive (Maratou et al., 2007; Thewissen et al., 2014) and become obligate glucose utilizers when activated (Healy et al., 2002; Calder et al., 2007; Maratou et al., 2007); thus, increased circulating insulin during HS and PF might be caused by intestinal-derived endotoxin, in an attempt to maximize glucose uptake by immune cells.

Compared with ZSCON, both PF and HS decreased circulating glucose, and this agrees with previous reports (Nardone et al., 1997; Rhoads et al., 2009; O'Brien et al., 2010; Sanz Fernandez et al., 2015a,b). The effects of HS on circulating glucose are inconsistent, as some have demonstrated increased glucose during a ther- mal load (Shwartz et al., 2009; Wheelock et al., 2010; Pearce et al., 2013b). Many factors might explain the inconsistences in circulating glucose, such as severity of the heat load, species differences, feed composition, previous acclimatization, and physiological state.

Although both PF and HS steers had increased circulating NEFA compared with ZSCON, PF calves had a more robust increase in plasma NEFA than HS steers. The increase in NEFA is bioenergetically expected, because both groups were on a lowered plane of nutrition, and adipose mobilization is a homeorhetic response to maintain energy supply for metabolic processes. Our group has previously reported that heat-stressed ruminants do not mobilize as much adipose tissue as their PF counterparts (Rhoads et al., 2009; O'Brien et al., 2010; Al-Qaisi et al., 2020). In this study, we utilized an ad libitum control, and this likely explains why we detected a small increase in NEFA in HS steers. However, the decrease in NEFA in HS compared with PF steers agrees with many previous reports in a variety of species (O'Brien et al., 2010; Pearce et al., 2014; Sanz Fernandez et al., 2015b), likely due to increased insulin, 


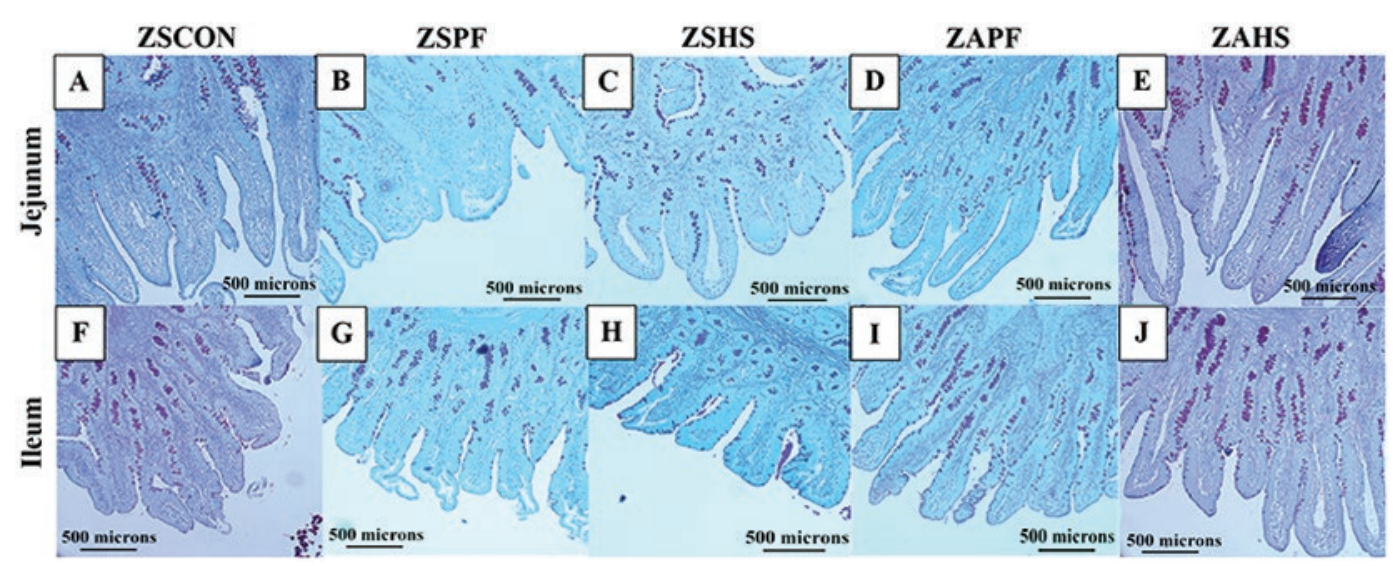

Figure 2. Representative images of periodic acid-Schiff stained jejunum (panels A-E) and ileum (panels F-J) for treatments ZSCON (A and F), ZSPF (B and G), ZSHS (C and H), ZAPF (D and I), and ZAHS (E and J), respectively. Treatments: ZSCON $=$ thermoneutral ad libitum control diet with ZS, ZSPF = pair-fed $75 \mathrm{mg} / \mathrm{kg}$ ZS diet, ZAPF = pair-fed $40 \mathrm{mg} / \mathrm{kg} \mathrm{ZA}$ and $35 \mathrm{mg} / \mathrm{kg}$ ZS diet, ZSHS = heat stress ad libitum $75 \mathrm{mg} / \mathrm{kg}$ ZS diet, and ZAHS = heat stress ad libitum $40 \mathrm{mg} / \mathrm{kg} \mathrm{ZA}$ and $35 \mathrm{mg} / \mathrm{kg} \mathrm{ZS}$ diet. ZA = Zn amino acid complex; ZS = Zn sulfate.

which is a potent antilipolytic hormone (Baumgard and Rhoads, 2013).

One of the strategies some animals utilize to dissipate heat is panting (hyperventilation). Panting decreases blood $\mathrm{CO}_{2}$, which can cause respiratory alkalosis (Benjamin, 1981). The circulating buffering system primarily uses $\mathrm{HCO}_{3}$ to maintain a constant $\mathrm{pH}$ and prevent acidosis, and low blood $\mathrm{HCO}_{3}$ observed during $\mathrm{HS}$ is indicative of an $\mathrm{HCO}_{3}: \mathrm{CO}_{2}$ imbalance, resulting in acidotic conditions (Sanchez et al., 1994). In the current study, overall blood $\mathrm{pH}$ was not changed by treatment, but $\mathrm{pCO}_{2}, \mathrm{HCO}_{3}, \mathrm{TCO}_{2}, \mathrm{BEx}$, and Na were all reduced by HS, and this agrees with other studies (Schneider et al., 1984; West et al., 1991; Al-Qaisi et al., 2020). Furthermore, ZAHS increased $\mathrm{pCO}_{2}, \mathrm{HCO}_{3}$, and $\mathrm{Na}$, and tended to increase $\mathrm{TCO}_{2}$ and BEx compared with ZSHS controls. Although the mechanism is not clear, the aforementioned results might suggest that ZA supplementation reduced the strain on the blood gas system during HS.

In summary, our results indicate that dietary ZA improves intestinal plasticity during both HS and PF. Dietary ZA reduced Tr after $4 \mathrm{~d}$ of heat exposure and improved some blood gas variables, indicative of ameliorated heat strain. Collectively, this experiment demonstrates that ZA protects a variety of physiological systems during HS. Presumably, the described physiological changes may translate into improved animal and herd performance during the warm summer months.

\section{ACKNOWLEDGMENTS}

This project was supported by Zinpro Corporation (Eden Prairie, MN) and the Norm Jacobson endowed professorship (Iowa State University, Ames, IA). J. M.
DeFrain and D. H. Kleinschmit are Zinpro employees. The other authors have not stated any conflicts of interest.

\section{REFERENCES}

Al-Qaisi, M., E. J. Mayorga, E. A. Horst, S. K. Kvidera, C. S. McCarthy, M. A. Abeyta, B. M. Goetz, H. A. Ramirez-Ramirez, L. L. Timms, and L. H. Baumgard. 2020. Validating a heat stress model: The effects of an electric heat blanket and nutritional plane on lactating dairy cows. J. Dairy Sci. 103:5550-5560. https://doi .org/10.3168/jds.2019-17543.

Ashraf, S., H. Zaneb, M. S. Yousaf, A. Ijaz, M. U. Sohail, S. Muti, M. M. Usman, S. Ijaz, and H. Rehman. 2013. Effect of dietary supplementation of prebiotics and probiotics on intestinal microarchitecture in broilers reared under cyclic heat stress. J. Anim. Physiol. Anim. Nutr. (Berl.) 97:68-73. https://doi.org/10.1111/jpn.12041.

Baumgard, L. H., and R. P. Rhoads Jr.. 2013. Effects of heat stress on postabsorptive metabolism and energetics. Annu. Rev. Anim. Biosci. 1:311-337. https://doi.org/10.1146/annurev-animal-031412 $-103644$.

Benjamin, M. M. 1981. Fluid and electrolytes. In Outline of Veterinary Clinical Pathology. Iowa State Univ. Press, Ames, IA.

Calder, P. C., G. Dimitriadis, and P. Newsholme. 2007. Glucose metabolism in lymphoid and inflammatory cells and tissues. Curr. Opin. Clin. Nutr. Metab. Care 10:531-540. https://doi.org/10 .1097/MCO.0b013e3281e72ad4.

Ceciliani, F., J. J. Ceron, P. D. Eckersall, and H. Sauerwein. 2012. Acute phase protein in ruminants. J. Proteomics 75:4207-4231. https://doi.org/10.1016/j.jprot.2012.04.004.

Dokladny, K., R. Lobb, W. Wharton, T. Y. Ma, and P. L. Moseley. 2010. LPS-induced cytokine levels are repressed by elevated expression of HSP70 in rats: possible role of NF-kappaB. Cell Stress Chaperones 15:153-163. https://doi.org/10.1007/s12192-009-0129 $-6$.

Eze, J. I., L. C. Ayogu, F. O. Abonyi, and U. U. Eze. 2015. The beneficial effect of dietary zinc supplementation on anaemia and immunosuppression in Trypanosoma brucei infected rats. Exp. Parasitol. 154:87-92. https://doi.org/10.1016/j.exppara.2015.04.015.

Ferraris, R. P., and H. V. Carey. 2000. Intestinal transport during fasting and malnutrition. Annu. Rev. Nutr. 20:195-219. https:// doi.org/10.1146/annurev.nutr.20.1.195.

Finamore, A., M. Massimi, L. Conti Devirgiliis, and E. Mengheri. 2008. Zinc deficiency induces membrane barrier damage and increases 
neutrophil transmigration in caco-2 cells. J. Nutr. 138:1664-1670. https://doi.org/10.1093/jn/138.9.1664.

Foster, M., and S. Samman. 2012. Zinc and regulation of inflammatory cytokines: Implications for cardiometabolic disease. Nutrients 4:676-694. https://doi.org/10.3390/nu4070676.

Gabler, N. K., D. Koltes, S. Schaumberger, G. R. Murugesan, and N. Reisinger. 2018. Diurnal heat stress reduces pig intestinal integrity and increases endotoxin translocation. Transl. Anim. Sci. 2:1-10. https://doi.org/10.1093/tas/txx003.

Garcia-Lazaro, J. F., F. Thieringer, S. Lüth, P. Czochra, E. Meyer, I. B. Renteria, P. R. Galle, A. W. Lohse, J. Herkel, and S. Kanzler. 2005. Hepatic over-expression of TGF-beta1 promotes LPSinduced inflammatory cytokine secretion by liver cells and endotoxemic shock. Immunol. Lett. 101:217-222. https://doi.org/10 .1016/j.imlet.2005.06.003.

Goodlad, R. A., J. A. Plumb, and N. A. Wright. 1988. Epithelial cell proliferation and intestinal absorptive function during starvation and refeeding in the rat. Clin. Sci. (Lond.) 74:301-306. https://doi .org/10.1042/cs0740301.

Hall, D. M., K. R. Baumgardner, T. D. Oberley, and C. V. Gisolfi. 1999. Splanchnic tissues undergo hypoxic stress during whole body hyperthermia. Am. J. Physiol. 276:G1195-G1203. https://doi.org/ 10.1152/ajpgi.1999.276.5.G1195.

Healy, D. A., R. W. G. Watson, and P. Newsholme. 2002. Glucose, but not glutamine, protects against spontaneous and anti-Fas antibody-induced apoptosis in human neutrophils. Clin. Sci. (Lond.) 103:179-189. https://doi.org/10.1042/cs1030179.

Horst, E. A., E. J. Mayorga, M. Al-Qaisi, M. A. Abeyta, B. M. Goetz, H. Ramirez Ramirez, D. H. Kleinschmit, and L. H. Baumgard. 2019. Effects of dietary zinc source on the metabolic and immunological response to lipopolysaccharide in lactating Holstein dairy cows. J. Dairy Sci. 102:11681-11700. https://doi.org/10.3168/jds 2019-17037.

Hou, Y., L. Wang, W. Zhang, Z. Yang, B. Ding, H. Zhu, Y. Liu, Y. Qiu, Y. Yin, and G. Wu. 2012. Protective effects of N-acetylcysteine on intestinal functions of piglets challenged with lipopolysaccharide. Amino Acids 43:1233-1242. https://doi.org/10.1007/ s00726-011-1191-9.

Iseri, V. J., and K. C. Klasing. 2013. Dynamics of the systemic components of the chicken (Gallus gallus domesticus) immune system following activation by Escherichia coli; Implications for the costs of immunity. Dev. Comp. Immunol. 40:248-257. https://doi.org/ 10.1016/j.dci.2013.02.005.

Jarosz, M., M. Olbert, G. Wyszogrodzka, K. Mlyniec, and T. Librowski. 2017. Antioxidant and anti-inflammatory effects of zinc. Zincdependent NF- $\mathrm{B}$ signaling. Inflammopharmacology 25:11-24. https://doi.org/10.1007/s10787-017-0309-4.

Kadzere, C. T., M. R. Murphy, N. Silanikove, and E. Maltz. 2002. Heat stress in lactating dairy cows: A review. Livest. Prod. Sci. 77:59-91. https://doi.org/10.1016/S0301-6226(01)00330-X.

Koch, F., U. Thom, E. Albrecht, R. Weikard, W. Nolte, B. Kuhla, and C. Kuehn. 2019. Heat stress directly impairs gut integrity and recruits distinct immune cell populations into the bovine intestine. Proc. Natl. Acad. Sci. USA 116:10333-10338. https://doi.org/10 $.1073 /$ pnas. 1820130116.

Kregel, K. C., P. T. Wall, and C. V. Gisolfi. 1988. Peripheral vascular responses to hyperthermia in the rat. J. Appl. Physiol. 64:25822588. https://doi.org/10.1152/jappl.1988.64.6.2582.

Kvidera, S. K., E. A. Horst, M. Abuajamieh, E. J. Mayorga, M. V. Sanz Fernandez, and L. H. Baumgard. 2017a. Glucose requirements of an activated immune system in lactating Holstein cows. J. Dairy Sci. 100:2360-2374. https://doi.org/10.3168/jds.2016 $-12001$.

Kvidera, S. K. E. A., E. A. Horst, E. J. Mayorga, M. V. Sanz Fernandez, M. Abuajamieh, and L. H. Baumgard. 2017b. Estimating glucose requirements of an activated immune system in growing pigs. J. Anim. Sci. 95:5020-5029. https://doi.org/10.2527/jas2017.1830.

Kvidera, S. K., E. A. Horst, M. V. Sanz Fernandez, M. Abuajamieh, S. Ganesan, P. J. Gorden, H. B. Green, K. M. Schoenberg, W. E. Trout, A. F. Keating, and L. H. Baumgard. 2017c. Characterizing effects of feed restriction and glucagon-like peptide 2 administra- tion on biomarkers of inflammation and intestinal morphology. J. Dairy Sci. 100:9402-9417. https://doi.org/10.3168/jds.2017-13229.

Lambert, G. P., C. V. Gisolfi, D. J. Berg, P. L. Moseley, L. W. Oberley, and K. C. Kregel. 2002. Selected contribution: Hyperthermiainduced intestinal permeability and the role of oxidative and nitrosative stress. J. Appl. Physiol. 92:1750-1761. https://doi.org/10 .1152/japplphysiol.00787.2001.

Lee, E. J., Y. M. Heo, J. H. Choi, H. O. Song, J. S. Ryu, and M. H. Ahn. 2008. Suppressed production of pro-inflammatory cytokines by LPS-activated macrophages after treatment with Toxoplasma gondii lysate. Korean J. Parasitol. 46:145-151. https://doi.org/10 .3347/kjp.2008.46.3.145.

Liu, F.. J. J. Cottrell, J. B. Furness, L. R. Rivera, F. W. Kelly, U. Wijesiriwardana, R. V. Pustovit, L. J. Fothergill, D. M. Bravo, P. Celi, B. J. Leury, N. K. Gabler, and F. R. Dunshea. 2016. Selenium and vitamin $\mathrm{E}$ together improve intestinal epithelial barrier function and alleviate oxidative stress in heat-stressed pigs. Exp. Physiol. 101:801-810. https://doi.org/10.1113/EP085746.

Maratou, E., G. Dimitriadis, A. Kollias, E. Boutati, V. Lambadiari, P. Mitrou, and S. A. Raptis. 2007. Glucose transporter expression on the plasma membrane of resting and activated white blood cells. Eur. J. Clin. Invest. 37:282-290. https://doi.org/10.1111/j.1365 $-2362.2007 .01786 . x$.

Mayorga, E. J., S. K. Kvidera, E. A. Horst, M. Al-Qaisi, M. J. Dickson, J. T. Seibert, S. Lei, A. F. Keating, J. W. Ross, R. P. Rhoads, Z. J. Rambo, M. E. Wilson, and L. H. Baumgard. 2018. Effects of zinc amino acid complex on biomarkers of gut integrity and metabolism during and following heat stress or feed restriction in pigs. J. Anim. Sci. 96:4173-4185. https://doi.org/10.1093/jas/ sky293.

Nardone, A., N. Lacetera, U. Bernabucci, and B. Ronchi. 1997. Composition of colostrum from dairy heifers exposed to high air temperatures during late pregnancy and the early postpartum period. J. Dairy Sci. 80:838-844. https://doi.org/10.3168/jds.S0022 -0302(97)76005-3.

Nayeri, A., N. C. Upah, E. Sucu, M. V. Sanz Fernandez, J. M. DeFrain, P. J. Gorden, and L. H. Baumgard. 2014. Effect of the ratio of zinc amino acid complex to zinc sulfate on the performance of Holstein cows. J. Dairy Sci. 97:4392-4404. https://doi.org/10 $.3168 /$ jds.2013-7541.

Noah, T. K., B. Donahue, and N. F. Shroyer. 2011. Intestinal development and differentiation. Exp. Cell Res. 317:2702-2710. https:// doi.org/10.1016/j.yexcr.2011.09.006.

NRC (National Research Council). 2000. Nutrient Requirements of Beef Cattle. 7th rev. ed. Nat. Acad. Press, Washington, DC.

NRC (National Research Council). 2001. Nutrient Requirements of Dairy Cattle.7th rev. ed. Nat. Acad. Press, Washington, DC.

O'Brien, M. D., R. P. Rhoads, S. R. Sanders, G. C. Duff, and L. H. Baumgard. 2010. Metabolic adaptations to heat stress in growing cattle. Domest. Anim. Endocrinol. 38:86-94. https://doi.org/10 .1016/j.domaniend.2009.08.005.

Pearce, S. C., N. K. Gabler, J. W. Ross, J. Escobar, J. F. Patience, R. P. Rhoads, and L. H. Baumgard. 2013a. The effects of heat stress and plane of nutrition on metabolism in growing pigs. J. Anim. Sci. 91:2108-2118. https://doi.org/10.2527/jas.2012-5738.

Pearce, S. C., V. Mani, R. L. Boddicker, J. S. Johnson, T. E. Weber, J. W. Ross, R. P. Rhoads, L. H. Baumgard, and N. K. Gabler. 2013b. Heat stress reduces intestinal barrier integrity and favors intestinal glucose transport in growing pigs. PLoS One 8:e70215. https://doi .org/10.1371/journal.pone.0070215.

Pearce, S. C., V. Mani, T. E. Weber, R. P. Rhoads, J. F. Patience, L. H. Baumgard, and N. K. Gabler. 2013c. Heat stress and reduced plane of nutrition decreases intestinal integrity and function in pigs. J. Anim. Sci. 91:5183-5193. https://doi.org/10.2527/jas.2013 -6759 .

Pearce, S. C., M. V. Sanz Fernandez, J. H. Hollis, L. H. Baumgard, and N. K. Gabler. 2014. Short-term exposure to heat stress attenuates appetite and intestinal integrity in growing pigs. J. Anim. Sci. 92:5444-5454. https://doi.org/10.2527/jas.2014-8407.

Pearce, S. C., M. V. Sanz Fernandez, J. Torrison, M. E. Wilson, L. H. Baumgard, and N. K. Gabler. 2015. Dietary organic zinc at- 
tenuates heat-stressed induced changes in intestinal integrity and metabolism. J. Anim. Sci. 93:4702-4713. https://doi.org/10.2527/ jas.2015-9018.

Rhoads, M. L., R. P. Rhoads, M. J. VanBaale, R. J. Collier, S. R. Sanders, W. J. Weber, B. A. Crooker, and L. H. Baumgard. 2009. Effects of heat stress and plane of nutrition on lactating Holstein cows: I. Production, metabolism, and aspects of circulating somatotropin. J. Dairy Sci. 92:1986-1997. https://doi.org/10.3168/ jds.2008-1641.

Rodriguez, P., N. Darmon, P. Chappuis, C. Candalh, M. A. Blaton, C. Bouchaud, and M. Heyman. 1996. Intestinal paracellular permeability during malnutrition in Guinea pigs: Effect of high dietary zinc. Gut 39:416-422. https://doi.org/10.1136/gut.39.3.416.

Sanchez, W. K., M. A. McGuire, and D. K. Beede. 1994. Macromineral nutrition by heat stress interactions in dairy cattle: Review and original research. J. Dairy Sci. 77:2051-2079. https://doi.org/10 .3168/jds.S0022-0302(94)77150-2.

Santos, R. R., A. Awati, P. J. Roubos-van den Hil, M. H. TersteegZijderveld, P. A. Koolmees, and J. Fink-Gremmels. 2015. Quantitative histo-morphometric analysis of heat-stress-related damage in the small intestines of broiler chickens. Avian Pathol. 44:19-22. https://doi.org/10.1080/03079457.2014.988122.

Sanz Fernandez, M. V., J. S. Johnson, M. Abuajamieh, S. K. Stoakes, J. T. Seibert, L. Cox, S. Kahl, T. H. Elsasser, J. W. Ross, S. C. Isom, R. P. Rhoads, and L. H. Baumgard. 2015a. Effects of heat stress on carbohydrate and lipid metabolism in growing pigs. Physiol. Rep. 3:e12315. https://doi.org/10.14814/phy2.12315.

Sanz Fernandez, M. V., S. C. Pearce, N. K. Gabler, J. F. Patience, M. E. Wilson, M. T. Socha, J. L. Torrison, R. P. Rhoads, and L. H. Baumgard. 2014. Effects of supplemental zinc amino acid complex on gut integrity in heat-stressed growing pigs. Animal 8:43-50. https://doi.org/10.1017/S1751731113001961.

Sanz Fernandez, M. V., S. K. Stoakes, M. Abuajamieh, J. T. Seibert, J. S. Johnson, E. A. Horst, R. P. Rhoads, and L. H. Baumgard. 2015b. Heat stress increases insulin sensitivity in pigs. Physiol. Rep. 3:e12478. https://doi.org/10.14814/phy2.12478.

Sarkar, P., T. Saha, I. A. Sheikh, S. Chakraborty, J. Aoun, M. K. Chakrabarti, V. M. Rajendran, N. A. Ameen, S. Dutta, and K. M. Hoque. 2019. Zinc ameliorates intestinal barrier dysfunctions in shigellosis by reinstating claudin- 2 and -4 on the membranes. Am. J. Physiol. Gastrointest. Liver Physiol. 316:G229-G246. https:// doi.org/10.1152/ajpgi.00092.2018.

Schneider, P. L., D. K. Beede, C. J. Wilcox, and R. J. Collier. 1984. Influence of dietary sodium and potassium bicarbonate and total potassium on heat-stressed lactating dairy cows. J. Dairy Sci 67:2546-2553. https://doi.org/10.3168/jds.S0022-0302(84)81611 -2 .

Shwartz, G., M. Rhoads, M. VanBaale, R. Rhoads, and L. H. Baumgard. 2009. Effects of a supplemental yeast culture on heat-stressed lactating Holstein cows. J. Dairy Sci. 92:935-942. https://doi.org/ 10.3168/jds.2008-1496.

Steel, D. M., and A. S. Whitehead. 1994. The major acute phase reactants: C-reactive protein, serum amyloid $\mathrm{P}$ component and serum amyloid A protein. Immunol. Today 15:81-88. https://doi.org/10 .1016/0167-5699(94)90138-4.

Sturniolo, G. C., V. Di Leo, A. Ferronato, A. D'Odorico, and R. D'Incà. 2001. Zinc supplementation tightens "leaky gut" in Crohn's disease. Inflamm. Bowel Dis. 7:94-98. https://doi.org/10.1097/ 00054725-200105000-00003.

Sturniolo, G. C., W. Fries, E. Mazzon, V. Di Leo, M. Barollo, and R. D'Inca. 2002. Effect of zinc supplementation on intestinal permeability in experimental colitis. J. Lab. Clin. Med. 139:311-315. https://doi.org/10.1067/mlc.2002.123624.
Thewissen, M. M., J. van de Gaar, A. T. den Boer, M. J. Munsters, E. E. Blaak, and A. Duijvestijn. 2014. Monocytes, but not T cells, respond to insulin with Akt(S473) phosphorylation independent of the donor glucometabolic state. Diabetes Metab. Res. Rev. 30:323332. https://doi.org/10.1002/dmrr.2498.

Vasconcelos, J. T., and M. L. Galyean. 2007. Nutritional recommendations of feedlot consulting nutritionists: The 2007 Texas Tech University survey. J. Anim. Sci. 85:2772-2781. https://doi.org/10 $.2527 /$ jas.2007-0261.

Waeytens, A., M. De Vos, and D. Laukens. 2009. Evidence for a potential role of metallothioneins in inflammatory bowel diseases. Mediators Inflamm. 2009:729172. https://doi.org/10.1155/2009/ 729172.

Waldron, M. R., A. E. Kulick, A. W. Bell, and T. R. Overton. 2006. Acute experimental mastitis is not causal toward the development of energy-related metabolic disorders in early postpartum dairy cows. J. Dairy Sci. 89:596-610. https://doi.org/10.3168/jds.S0022 $-0302(06) 72123-3$

Wang, X., M. C. Valenzano, J. M. Mercado, E. P. Zurbach, and J. M. Mullin. 2013. Zinc supplementation modifies tight junctions and alters barrier function of Caco-2 human intestinal epithelial layers. Dig. Dis. Sci. 58:77-87. https://doi.org/10.1007/s10620-012 -2328-8.

Wannemacher, R. W. Jr., F. A. Beall, P. G. Canonico, R. E. Dinterman, C. L. Hadick, and H. A. Neufeld. 1980. Glucose and alanine metabolism during bacterial infections in rats and rhesus monkeys. Metabolism 29:201-212. https://doi.org/10.1016/0026 -0495(80)90061-X.

Welsh, F. K. S., S. M. Farmery, K. MacLennan, M. B. Sheridan, G. R. Barclay, P. J. Guillou, and J. V. Reynolds. 1998. Gut barrier function in malnourished patients. Gut 42:396-401. https://doi.org/10 $.1136 /$ gut.42.3.396.

West, J. W., G. Mullinix, and T. G. Sandifer. 1991. Effects of bovine somatotropin on physiologic responses of lactating Holstein and Jersey cows during hot, humid weather. J. Dairy Sci. 74:840-851. https://doi.org/10.3168/jds.S0022-0302(91)78233-7.

Wheelock, J. B., R. P. Rhoads, M. J. VanBaale, S. R. Sanders, and L. H. Baumgard. 2010. Effects of heat stress on energetic metabolism in lactating Holstein cows. J. Dairy Sci. 93:644-655. https://doi .org/10.3168/jds.2009-2295.

Yan, Y. E., Y.-Q. Zhao, H. Wang, and M. Fan. 2006. Pathophysiological factors underlying heatstroke. Med. Hypotheses 67:609-617. https://doi.org/10.1016/j.mehy.2005.12.048.

Yoshizawa, F., T. Nagasawa, N. Nishizawa, and R. Funabiki. 1997. Protein synthesis and degradation change rapidly in response to food intake in muscle of food-deprived mice. J. Nutr. 127:11561159 .

Yunianto, V. D., K. Hayashi, S. Kaneda, A. Ohtsuka, and Y. Tomita. 1997. Effect of environmental temperature on muscle protein turnover and heat production in tube-fed broiler chickens. Br. J. Nutr. $77: 897-909$.

Zhang, S., R. I. Albornoz, J. R. Aschenbach, D. R. Barreda, and G. B. Penner. 2013. Short-term feed restriction impairs the absorptive function of the reticulo-rumen and total tract barrier function in beef cattle. J. Anim. Sci. 91:1685-1695. https://doi.org/10.2527/ jas.2012-5669.

Zhong, W., Q. Li, Q. Sun, W. Zhang, J. Zhang, X. Sun, X. Yin, X. Zhang, and Z. Zhou. 2015. Preventing gut leakiness and endotoxemia contributes to the protective effect of zinc on Alcoholinduced steatohepatitis in rats. J. Nutr. 145:2690-2698. https:// doi.org/10.3945/jn.115.216093. 